\title{
Reinforcing Father's Role to Develop Generation with "Merit"
}

\author{
Wisroni \\ Department of Non-Formal Education, \\ Faculty of Education UniversitasNegeri Padang \\ Padang, Indonesia \\ wisronicon@gmail.com
}

\author{
Vevi Sunarti \\ Department of Non-Formal Education, \\ Faculty of Education UniversitasNegeri Padang \\ Padang, Indonesia \\ vj_vevi@yahoo.com
}

\begin{abstract}
Education is available anywhere and anytime for the whole life, so that the setting of this education happens in informal, formal and non-formal form. The education in family is a part of informal setting, it is the first and main education and plays a very big role in determining someone's life.The main educators in family are father and mother. In the society stigma, a father's figure is more emphasized as the breadwinner and a mother's figure is the educator or the caretaker in the family. In fact, a father's responsibility is not just as the breadwinner, but also responsible to educate the children to create a generation with merit. This writing will begin with the rationale of reinforcing father's role in family education. Then, the family's role in education, that is as the first and main education; father's role in education and proposing the studies and the relevant result of the researches: finding and discussion; and conclusion and suggestion.
\end{abstract}

Keywords - reinforcing; father; the generation; "merit"

\section{INTRODUCTION}

The role of the family in education of a nation is very important because family is the first and main place in education and the character's growing to the family members who will colors the next generation's characteristics[1]. The family is the lowest core group in society organization which natural in conducting the education. In the family, the children are prepared to face the growing phases as the provision to enter the adults' world in the middle of the society.

The parents is the first party to provide the children with basics education like the religious act and behavior, manner, love, security, the basics for the discipline, and the other basics. Too, the parents also play the role to provide the children about the values and behaviors like what have been taught in the school, so there is a continuity and correlation between values education at home and in the school.

The main educators in the family are father and mother. The reinforcing of father's role becomes very important, at least for these three reasons. First, because a father is the head of the family. In a family, father has an important role. As the head of the family, the father is the leader of the family. Without putting mother's role aside, as the leader, a father surely has a very significant role in deciding which way or the destination his family will take. A father has to give anything needed for family education, such as guidance, guideline, and a model, and any other education tools in interactions process with children in the family.

Second, the reinforcing of a father's role becoming interesting to discuss since nowadays many mothers who used to play the role as the housewives have become career woman. The business as the career woman and the workers causes less opportunity and attention toward their children's education. The decrease of mother's opportunity and attention can be compensated with father's role.

Third, the stigma in society that proposes a figure of a father is more emphasized as the breadwinner and mother as the educator and the caretaker is still strong. This is the wrong perception and the mindset that should be straightened. The main assignment of a father is not just about economy things, but also as the determinant for family education's direction to develop a generation with merit[2]. If this stigma shifts, in the future, there will be a synergic collaboration between a father's and mother's role in children education, which in the end will create a generation with merit.

\section{REVIEW OF RELATED LITERATURES}

\section{A. The Role of the Family in Education}

Education is an attempt of the adult human to construct children's personalities so that it fit with the norms and regulation in society life. Every adults in the society can be an educator, because educator is a basic social act for the growing and children's development to be a wise human.

The baby's age until the preschool education is the golden age simultaneously as the critical phase in human's life, which is very influential to the development of the children in the future. This age is the precise time to put the basics of physical skill development, language, socialemotional, self concept, arts, moral, and the religious values, so the attempts of all of the potencies development should 
be started in order to gain an optimal growth and development [3].

The children's education is available in three setting; they are informal, formal, and non-formal. The education in the family is a part of informal education, and its role is very important [4](Education, Education, Student, Performance, \& Journal, 2012). The result of the research shows that the parents play the important role in children's education, which is showed by the children who has merit in study, followed by behavior improvement, socio-emotional stability, discipline, also the aspiration to study until university, even after working and have their own households [5].

Family is the important environment for children, because they interact with meaningful people in their life and most of the children's life is spent in the family[6]. In the family, children gain many experience to grow and develop to the adultery age. According to [7], the family role in children education is for children personality development; supporting the education in children's school, giving first experiences during childhood, guarantee the emotional life of the children, planting moral and social basics in children, putting the basic of religious education, motivating and encouraging children's success, introducing variety of knowledge and basic skills, caring children's health so they will feel comfortable to study, and as the creator of the happiness in the present and hereafter for the children [8].

To implement this role well, the parents have to have the satisfy quality. Parents have to understand the nature and their role as the parents to raise a child, to provide themselves with the knowledge of proper caretaking pattern, the knowledge about children's development and the education children should learn. In short term, the parents have to get themselves ready with many knowledge and skills needed in educating children.

\section{B. The Father's Role in education}

In the previous section has been explained the importance of reinforcing father's role in education, because father is the head of the family, the decrease of mother's time and attention toward children's education, and the society stigma that proposes the main educator in a family is mother[2]. The reinforcing of father's role can be observed from many studies' results as follow.

Mc. Adoo in his result toward the families in US and discussed it with the teachers found out that fathers who take a part of their children's education influences positively toward children adaptation and able to prepare children with the skills to face the challenges in society. Then, it was proposed that the children with those two skills are found in the families where the fathers play the role as: (1) provider (for facilities) (2) protector (3) Decision Maker (4) Child Specializer and educator, and (5) nurtured mother.

Then, according to [9], the role of the father is special because having positive effects for the children. How special is his role? "What's special about Father's Involvement?" According to him, there are 4 roles of the father: (1) Modeling adult male behavior (2) Making choices (3) Problem Solving Ability (4) Providing Financial and Emotional Support. The other researchers, especially who study the father's role in children education (fatherhood) suggests that the fathers who get involved in educating children actively will bring positive advantages that can be done by others.

This analysis is in line with the study result conducted by Kyle D. Priett. According to Pruett in his book Fatherneed: why father care is as essential as mother care for your child, the advantages of the father's involvement in educating children are as follows: first, the result of children's education is better. Some studies show that fathers who get involved in caretaking and playing with their little child will improve the intelligence (IQ), language skill, and cognitive capacity of the children.

Second, children will be ready mentally to enter school environment. They will be patient and be more able to handle the pressure and frustration related to the learning activity in the school compared to the children whose fathers are less attentive. Third, emotionally more stable. Fathers who get involved early since the baby was born will make the children's emotion be more stable, more confident to explore the environment around them. At the time they are becoming adults, they will have social connection with their friends better, and also a little possibility will cause a problem at home, school, and the environment around. Fourth, the children will enter schooling age calmly and a little possibility of having depression, showing disruptive behavior and lying. The children will also show a more prosocial behavior. Fifth, the boys tend to be a good student at home the girltend to have a more strong confident.

Beside, a number of surveys conclude that the children who close to the fathers are more possible to have a good physical health and better emotional. The performance in the class is better, and tend to avoid the teenage misbehavior such as drugs, violence, and other deviate behavior.

\section{RESULT AND DISCUSSIONS}

Father is a figure with important role in family. The function of a father is, obviously, different with mothers'. Nowadays, the substation and implementation and implementation of those things have changed. It is because the change that happens in the structure and relationship pattern between family members [15] and there is also the change of paradigm of the parents' role related to public and domestic role because the prior changes of how the Devaney family formed [10].

The research on 17,000 students in England conducted by Oxford University yields a conclusion that there is a relevant relationship between father's closeness with 
student's academic success. The other research conducted by Illinois University, U.S., concludes that student who has an attentive father who will make his time just to ask what the student learned at school and the social activities, and relationship with his/her friends, tend to have good performance and better achievement at school compared to the student who get no attention from his/her father [11].

Because this big influence of the father's role, it becomes a father's responsibility to pay more attention during children's development age since little and make a close relationship with the child[12].

To be more specific, from the researches about family role, it is found out that most of the problematic students are growing up in a family with fathers who less attentive, and concern to the family [13]. In a family where father does not get involved in educating his children, the children lose the chances to learn about determination, responsibility, shame, right fellowship, controlling anger, and managing the emotion [14].

The nest researches results also concludes that aggressive behavior, anti-social, and the disorder act of the children related to the father's role in the family[16]. Gottman recalls that children whose fathers do not get involved in their lives will find it harder to find the balance between determination and control [11].

\section{CONCLUSION AND SUGGESTION}

The concept of parenting in children's education that used to be mother centered (mothering) shifts to be motherfather-centered, altogether. The research, then, studies the role of the father (fathering) comprehensively.

The new and revolutionary ideas appeared to the surface. Many researchers find out that fathering impact positively to the children development. The research result on children who do not get the attention from the father shows a lame development. The group of children with less attention from the fathers cause the decreasing of their academic skill, blocking social personality, children fragile personality, or further, for the boys, their masculine characteristics can be vague.

A lot of studies and research results that shows reinforcing the father's role in children education in family is very important. In a father's figure, children learn about determination, responsibility, shame, right fellowship, controlling the anger, and controlling the emotion, etc. With the existence of the father's figure beside mothers' in educating children, it will be able to build a strong and with merit generation.

One of the attempts to reinforce father's role in producing a generation with quality and merit by involving himself directly in children's life. This self-involvement can be done by: (1) controlling the study schedule and learning method. The children have to be familiarized to study regularly, repeating the lesson from the school, and make them understand the time for playing and studying (2)monitoring the academic skill development of the children by checking the examination and practice score (3)monitoring the personality development consist of demeanor, moral, and behavior. It can be done by communicating with children's homeroom teacher to find out children development at school (4)monitoring study hours effectiveness at school. The parents can ask what their children do during school hours, the assignments, so that the ideal learning at school will be effective.

Beside the attempts above, the other things to do is helping the children to recognize themselves (strengths and weakness), helping them to develop the potency that suits their talents and interests and helping them to put a strong foundation to their success in life and also helping them to plan their lives. And also, avoid the unrealized mistakes in educating children, they are: (1) growing the bad/scared feeling and minder; (2) to be arrogant person toward others; (3) familiarizing children with wasteful life; (4) always fulfilling their requests; (5) too hard and strict in handling the children; (6) too stingy (beyond proper); (7) not loving them wholeheartedly; and (8) too have good presume toward children.

\section{References}

[1] Kreidl, M., Štípková, M., \&Hubatková, B. (2017). Parental separation and children's education in a comparative perspective: Does the burden disappear when separation is more common? Demographic Research, 36(1), 73-110. https://doi.org/10.4054/DemRes.2017.36.3

[2] Plantin, L., Olukoya, A. A., \&Ny, P. (2011). Positive Health Outcomes of Fathers' Involvment in Pregnancy and Childbirth Paternal Support: A Scope Study Literature Review. Fathering: A Journal of Theory, Research, and Practice about Men as Fathers, 9(1), 87-102. https://doi.org/10.3149/fth.0901.87

[3] Sujiono, Y. N. (2009). KonsepDasarPendidikanAnakUsiaDini. Jakarta: PT. Indeks.

[4] Education, F., Education, F., Student, I., Performance, A., \& Journal, M. (2012). Family education, 2, 1-7. https://doi.org/10.17583/remie.2012.438.http

[5] Hasan, M. (2011). PendidikanAnakUsiaDini. Yogyakarta: Diva Press.

[6] Russell, J. L., Knutson, K., \& Crowley, K. (2013). Informal learning organizations as part of an educational ecology: Lessons from collaboration across the formal-informal divide. Journal of Educational Change, 14(3), 259-281. https://doi.org/10.1007/s10833-012-9203-4

[7] Hasbullah. (1997). PendidikandalamKeluarga. Bandung: RinekaCipta.

[8] Davis-Kean, P. E. (2005). The Influence of Parent Education and Family Income on Child Achievement: The Indirect Role of Parental Expectations and the Home Environment. Journal of Family Psychology, 19(2), 294-304. https://doi.org/10.1037/08933200.19.2.294

[9] Rilley, R.W. \& Shalala, D. . (2000). A Call Commitment: Fathers' Involvement in Children's Learning. US Dep. Of Education \& US Dep. of Healtba and Human Services.

[10] E., O'brien, M. U., Tavegia, M., \&Resnik, H. (2005). Promoting Children's Ethical Development through Social and Emotional Learning. New Directions for Youth Development.

[11] Fagbeminiyi, F. (2011). The Role of Parents in Early Childhood Education: A Case Study of Ikeja, Lagos State, Nigeria, 11(2). 
[12] Ceka, A. (2016). The Role of Parents in the Education of Children, 7(5), 61-64.

[13] Cronin, S., Becher, E. H., \& Powell, S. (2015). Parents and Stress: Understanding Experiences, Context and Responses. Extension Children.

[14] Bohling-philippi, V., Crim, C., Cutter-mackenzie, A., Edwards, C., Desjean-perrotta, B., Finch, K., ... Wilson, R. (2015). International Journal of Early Childhood, 3(1), 1-103.

[15] HemanElia. (2000). eran Ayah DalamMendidikAnak. JurnalVeritas, $1(1), 105-113$
[16] Department for Children Schools and Families. (2008). The impact of parental involvement on children's education, 1-12. https://doi.org/DCSF-00924-2008BKT-EN 